\title{
Phytochemicals, cytotoxicity, and genotoxicity of three Artocarpus species reveal arbutin in A. lacucha
}

\author{
Kowit Noikotr $^{\mathrm{a}, \mathrm{b}}$, Arunrat Chaveerach ${ }^{\mathrm{a}, \mathrm{c}, *}$, Runglawan Sudmoon ${ }^{\mathrm{a}, \mathrm{d}}$, Tawatchai Tanee ${ }^{\mathrm{a}, \mathrm{e}}$, \\ Natcha Patarapadungkit ${ }^{\mathrm{a}, \mathrm{f}}$ \\ ${ }^{a}$ Genetics and Environmental Toxicology Research Group, Khon Kaen University, \\ Khon Kaen 40002 Thailand \\ b Department of Biology, Faculty of Science, Ramkhamhaeng University, Bangkok 10240 Thailand \\ c Department of Biology, Faculty of Science, Khon Kaen University, Khon Kaen 40002 Thailand \\ d Faculty of Law, Khon Kaen University, Khon Kaen 40002 Thailand \\ e Faculty of Environment and Resource Studies, Mahasarakham University, \\ Maha Sarakham 44150 Thailand \\ ${ }^{f}$ Department of Pathology, Faculty of Medicine, Khon Kaen University, Khon Kaen 40002 Thailand \\ *Corresponding author, e-mail: raccha@kku.ac.th
}

Received 22 Aug 2017

Accepted 28 Jun 2018

\begin{abstract}
Leaves of three Artocarpus species were hexane and ethanol extracted and chemically analysed. Cytotoxicity and genotoxicity tests were performed on peripheral blood mononuclear cells. The main phytochemical in the hexane extracts was (Z)-9-octadecenamide (oleamide). The ethanol extracts showed 21\% 9,19-cyclolanost-24-en-3-ol in A. altilis, $19 \% n$-hexadecanoic acid in A. heterophyllus, and $21 \%$ arbutin in A. lacucha. The hexane extract of $A$. altilis gave an $\mathrm{IC}_{50}$ of $0.00035 \mathrm{mg} / \mathrm{ml}$ but no $\mathrm{IC}_{50}$ values for $A$. heterophyllus and A. lacucha extracts. Ethanol extracts of A. altilis and A. lacucha had $\mathrm{IC}_{50}$ values of 0.868 and $0.218 \mathrm{mg} / \mathrm{ml}$, respectively, but none for $A$. heterophyllus. All the hexane extracts showed non-significant DNA damage, while all the ethanol extracts significantly induced DNA damage $(p<0.05)$. A. lacucha leaf is newly reported as an alternative source of arbutin.
\end{abstract}

KEYWORDS: Artocarpus altilis, Artocarpus heterophyllus

\section{INTRODUCTION}

Asian countries possessing high biodiversity have consumed plant leaves in terms of cooking, i.e., vegetables, spices and seasoning, as well as fragrances. In addition, active compounds from extracts are applied in industries for the household, medicine, cosmetics and natural products. Leaves are sources of secondary metabolites which have long offered specific benefits to humans. Even though synthetic forms are comfortable amid daily use, they can be the cause of accumulated toxicity in the body amid long term use, for example, statin ${ }^{1,2}$ and finasteride, a 5- $\alpha$ reductase inhibitor ${ }^{3}$. There are many well-known phytochemical substances which have long been used as treatments for diseases ${ }^{4-6}$. Statin can be replaced with $\beta$-sitosterol in the treatment of high blood cholesterol ${ }^{7}$, which is a phytosterol synthesized only in plants for instance, Polygonum multiflorum ${ }^{8}$, Pygeum africanum ${ }^{4}$, Serenoa repens ${ }^{4}$, Gingko biloba ${ }^{4}$, Viola odorata ${ }^{9}$ and Cissus repens ${ }^{10}$. Good health is supported by complete foods, es- sential phytochemicals (especially from plants as foods), vegetables, fruits and others for body mechanisms. As well as exercise, they form the basis of public health. With the mentioned reasons, leaves are factories for phytochemical productions including 5- $\alpha$ reductase inhibitors ${ }^{5}$; eugenol, isoeugenol, chavicol, chavibetol, caryophyllene, sabinene, phellandrene, germacrene $\mathrm{A}$ and germacrene $\mathrm{D}$, and sesquiterpenes chavicol ${ }^{11}$; monoterpene, diterpene, triterpene and flavone ${ }^{12}$; squalene, $\alpha$-tocopherol, a form of vitamin $\mathrm{E}^{13,14}$. With the aforementioned phytochemicals, gas chromatography-mass spectrometry (GC-MS), an important tool for chemical identification of plant extracts has successfully been applied for screening and identification of phytochemicals in many plant groups ${ }^{14-17}$.

Plants found in genus Artocarpus have long been applied as foods and medicines. A. lacucha ('lakoocha') is one species of the genus shown to have resveratrol and oxyresveratrol in heartwood extracts and are employed as treatments of melanogenesis and microbial infections ${ }^{18-20}$. It is also a 
valuable tropical tree species employed for its fruit, furniture production, timber, and animal feeding. The lakoocha fruits are generally eaten fresh, but can be utilized in pickles and sauces. Two more species, A. altilis and A. heterophyllus are edible fruit plants available worldwide, i.e., the renowned breadfruit and jackfruit. The other parts of plants have been shown to exhibit identical benefits to the A. lacucha. However, research has yet to take place regarding their leaves as a factory for phytochemicals. Leaves can provide worthwhile usage and are sustainable. Hence the aim of this study focuses on phytochemicals and the toxicity testing of the three species, A. altilis, A. heterophyllus, and A. lacucha leaves.

\section{MATERIALS AND METHODS}

\section{Plant materials}

Three Artocarpus species, A. altilis (voucher no. Chaveerach 957), A. heterophyllus (voucher no. Chaveerach 958), and A. lacucha (voucher no. Chaveerach 956) were collected from Khon Kaen province, northeastern Thailand and were identified by Prof. Dr Arunrat Chaveerach. The voucher specimens were kept at Department of Biology, Faculty of Science, Khon Kaen University. Mature leaves were subsequently used for preparation of crude extracts via hexane and ethanol. Then, phytochemical analysis via GC-MS, cytotoxicity via haemacytometer counting, and genotoxicity by comet assay were performed.

\section{Phytochemical extracts}

Phytochemical extraction was performed as explained in the previous research ${ }^{17}$. The samples were rinsed with water and air-dried until water evaporated from the leaves. The dried leaves were subsequently finely ground with an electronic blender. Twenty gram of leaf powder was soaked in $120 \mathrm{ml}$ hexane or ethanol (analytical grade) for $72 \mathrm{~h}$ in the dark at room temperature. The mixture was then filtered through filter paper. The filtrates from this step were aliquoted, $1 \mathrm{ml}$ each, for GCMS analysis. For the remaining filtrates, the solvents were evaporated from the compounds using a vacuum concentrator (ScanVac LaboGene, Denmark) at $-20^{\circ} \mathrm{C}, 200 \mathrm{rpm}$ for $2 \mathrm{~h}$ until completely evaporated and solids were obtained. Dimethyl sulphoxide (DMSO) was gradually added to the solids until completely dissolved and concentration was calculated and set as stock extract maintained at $-20^{\circ} \mathrm{C}$ until cytotoxicity and genotoxicity exper- iments were conducted. Prior to toxicity experiments, the stock extracts were 10 -fold serial diluted for five levels in the culture medium as working concentrations.

\section{Analysis of plant extract component by GC-MS}

GC-MS analysis was performed as previously explained $^{17}$ using an Agilent Technologies GC 6890 N/5973 inert mass spectrometer fused with a capillary column $(30.0 \mathrm{~m} \times 250 \mu \mathrm{m} \times 0.25 \mu \mathrm{m})$. Helium gas was employed as the carrier at a constant flow rate of $1 \mathrm{ml} / \mathrm{min}$. The injection and masstransferred line temperature was set at $280^{\circ} \mathrm{C}$. The oven temperature was programmed for $70-120^{\circ} \mathrm{C}$ at $3{ }^{\circ} \mathrm{C} / \mathrm{min}$, held isothermally for $2 \mathrm{~min}$, then raised to $270^{\circ} \mathrm{C}$ at $5^{\circ} \mathrm{C} / \mathrm{min}$. A $1 \mu \mathrm{l}$ aliquot of the crude extract was injected in split-mode. The relative percentage of the crude constituents was expressed as a percentage using peak area normalization. Component identification was determined by comparing the obtained mass spectra with the reference compounds in the Wiley 7N.1 library.

\section{Isolation of human peripheral blood mononuclear cells (PBMCs)}

PBMCs were isolated from sodium heparin anticoagulated venous blood from a blood bank using Ficoll-Paque Plus (GE Healthcare) following the manufacturer's protocol. After isolation, the cells, with a viability of at least $98 \%$, were suspended at a concentration of $4-6 \times 10^{5}$ cells $/ \mathrm{ml}$ in modified RPMI-1640 medium supplemented with $2.05 \mathrm{mM}$ Lglutamine, $10 \% \mathrm{FBS}, 100 \mu \mathrm{g} / \mathrm{ml}$ streptomycin, and $100 \mathrm{U} / \mathrm{ml}$ penicillin.

\section{Extract treatment for cytotoxicity assay}

The prepared cells in the RPMI-1640 medium were seeded in 96-well plates, $125 \mu \mathrm{l}$ per well. Another $12.5 \mu \mathrm{l}$ of the proper extract working concentrations were added to the corresponding wells in triplicate. The plates were subsequently incubated in a humidified incubator at $37^{\circ} \mathrm{C}$ with supplied $5 \% \mathrm{CO}_{2}$ for $4 \mathrm{~h}$. The untreated cells, without addition of any extracts were applied as a negative control.

The cytotoxicity of the plant extracts was estimated by haemacytometer cell counting method. Post-treatment, the numbers of viable cells were counted under a microscope following erythrosine staining. To reveal the cytotoxicity of the plant extracts, cell viability was calculated as: (treated cells)/(negative control cells) and expressed as a percentage. All values were expressed as mean \pm SE. Doses inducing $50 \%$ inhibition of 
Table 1 Phytochemical constituents in the six extracts of three Artocarpus species.

\begin{tabular}{|c|c|c|c|c|c|c|c|}
\hline \multirow[t]{3}{*}{ Chemical } & \multirow[t]{3}{*}{ Formula } & \multicolumn{6}{|c|}{ Relative content (\%) } \\
\hline & & \multicolumn{2}{|c|}{ A. altilis } & \multicolumn{2}{|c|}{ A. heterophyllus } & \multicolumn{2}{|c|}{ A. lacucha } \\
\hline & & hexane & ethanol & hexane & ethanol & hexane & ethanol \\
\hline$\alpha$-Amyrin & $\mathrm{C}_{30} \mathrm{H}_{50} \mathrm{O}$ & 0.69 & 1.55 & 0.32 & 3.38 & 0.54 & 2.52 \\
\hline$\beta$-Amyrin & $\mathrm{C}_{30} \mathrm{H}_{50} \mathrm{O}$ & - & 1.33 & - & 2.99 & - & 3.22 \\
\hline Arbutin & $\mathrm{C}_{12} \mathrm{H}_{16} \mathrm{O}_{7}$ & - & - & - & - & - & 20.61 \\
\hline Benzyl $\beta$-D-glucoside & $\mathrm{C}_{12} \mathrm{H}_{18} \mathrm{O}_{6}$ & - & - & - & - & - & 0.49 \\
\hline Campesterol & $\mathrm{C}_{28} \mathrm{H}_{48} \mathrm{O}$ & 0.42 & 0.94 & & 1.22 & - & 1.69 \\
\hline Cholesta-4,6-dien-3-ol & $\mathrm{C}_{27} \mathrm{H}_{44}$ & - & - & - & 0.11 & - & 0.08 \\
\hline $\begin{array}{l}\text { (3ß)-9,19-Cyclolanost-24-en-3-ol, acetate } \\
\text { Cyclopenta[d]anthracene-8,11-dione, } 1,2 \text {, }\end{array}$ & $\mathrm{C}_{32} \mathrm{H}_{52} \mathrm{O}_{2}$ & - & 21.42 & - & 2.30 & - & - \\
\hline $\begin{array}{l}\text { 3,3a,4,5,6,6a,7,12-decahydro-3-isopropyl- } \\
\text { 6-methylene- }\end{array}$ & $\mathrm{C}_{21} \mathrm{H}_{26} \mathrm{O}_{2}$ & - & 0.27 & - & - & - & - \\
\hline Docosane & $\mathrm{C}_{22} \mathrm{H}_{46}$ & 0.93 & & 0.98 & & 0.79 & - \\
\hline $\begin{array}{l}\text { 1,10-Epoxy-4-methoxy-7-methyl-8- }(3,4 \text { - } \\
\text { methylenedioxyphenyl)-spiro }(5,5) \text { undeca- } \\
\text { 1,4-dien-3-one }\end{array}$ & $\mathrm{C}_{20} \mathrm{H}_{20} \mathrm{O}_{5}$ & - & - & 1.11 & - & - & - \\
\hline Friedelan-3-one & $\mathrm{C}_{30} \mathrm{H}_{50} \mathrm{O}$ & - & 0.47 & & - & - & 0.38 \\
\hline Germanicol & $\mathrm{C}_{30} \mathrm{H}_{50} \mathrm{O}$ & - & - & - & - & - & 0.45 \\
\hline Glycerin 1-monostearate & $\mathrm{C}_{21} \mathrm{H}_{42} \mathrm{O}_{4}$ & 1.63 & - & 1.61 & & 1.12 & 0.28 \\
\hline
\end{tabular}

cell viability (the $\mathrm{IC}_{50}$ value) were determined by plotting a graph between extract concentration and cell viability (\%). Then the concentrations showing $\mathrm{IC}_{50}$ were used for $\mathrm{LD}_{50}$ calculation ${ }^{21}$ to release hazardous levels ${ }^{22}$.

\section{Genotoxicity assay by comet assay}

The prepared cells in the 96-well plates were treated with the proper extracts at concentrations showing $\mathrm{IC}_{50}$ values. In the case of no $\mathrm{IC}_{50}$ values, the highest concentrations were applied. Positive control cells were exposed to UV light for $15 \mathrm{~min}$. The negative and vehicle controls as well as the incubation were performed as in the cytotoxicity assay. Subsequent to incubation, alkaline comet assay was performed as per the previously described method ${ }^{23}$. To quantify the level of DNA damage, the extent of DNA migration was defined using the 'Olive Tail Moment' (OTM), which is the relative amount of DNA in the tail of the comet multiplied by the median migration distance. Comets were observed at 360 magnifications with images obtained via an image analysis system (Isis) attached to a fluorescence microscope (Nikon, Japan), equipped with $560 \mathrm{~nm}$ excitation filter, $590 \mathrm{~nm}$ barrier filter and a CCD video camera PCO (Germany). At least 150 cells (50 cells for each triplicate slide) were examined for each experiment. Image analysis IMAGEJ was employed to analyse the OTM. All experiments were repeated at least three times. The nonparametric Mann-Whitney test was utilized for statistical analysis of the comet assay results and $p<0.05$ was considered as the statistically significant value.

\section{RESULTS AND DISCUSSION}

To study the majority of phytochemical constituents in plants, non-polar and polar solvents, hexane and ethanol were employed for extraction. The three studied species showed higher extract concentrations as a result of applying ethanol rather than hexane. This indicates that phytochemicals exist for the most part, in a polar group. Extract concentrations with hexane and ethanol were 3.5 and $18 \mathrm{mg} / \mathrm{ml} ; 2$ and $9.4 \mathrm{mg} / \mathrm{ml}$; and 2.45 and $29 \mathrm{mg} / \mathrm{ml}$ in A. altilis, A. heterophyllus, and $A$. lacucha, respectively.

Phytochemical constituents identified in all six extracts are shown in Table 1 . Total ionic chromatograms showing compounds of the studied extracts are displayed in Fig. 1. Phytochemicals constituting higher than $10 \%$ in the hexane extracts were $20 \%$ (Z)-9-octadecenamide in A. altilis; $26 \%$ (Z)-9-octadecenamide, 12\% hexacosane, and 10\% pentacosane in A. heterophyllus; and 23\% (Z)-9octadecenamide in A. lacucha. For the ethanol extracts, phytochemicals were $21 \%$ 9,19-cyclolanost24-en-3-ol and 15\% $n$-hexanedecanoic acid in A. altilis; $19 \% n$-hexadecanoic acid and $15 \% \beta$-sitosterol in A. heterophyllus; and $21 \%$ arbutin in A. lacucha.

For extract cytotoxicity, haemacytometer counting revealed that hexane $A$. altilis extract exhibited 
Table 1 (Cont.)

\begin{tabular}{|c|c|c|c|c|c|c|c|}
\hline \multirow[t]{3}{*}{ Chemical } & \multirow[t]{3}{*}{ Formula } & \multicolumn{6}{|c|}{ Relative content (\%) } \\
\hline & & \multicolumn{2}{|c|}{ A. altilis } & \multicolumn{2}{|c|}{ A. heterophyllus } & \multicolumn{2}{|c|}{ A. lacucha } \\
\hline & & hexane & ethanol & hexane & ethanol & hexane & ethanol \\
\hline Glycerol $\beta$-palmitate & $\mathrm{C}_{19} \mathrm{H}_{38} \mathrm{O}_{4}$ & 2.50 & 1.07 & 2.19 & 0.67 & 1.62 & 0.64 \\
\hline Heneicosane & $\mathrm{C}_{21} \mathrm{H}_{44}$ & 3.39 & - & 3.37 & - & 2.82 & - \\
\hline Hentriacontane & $\mathrm{C}_{31} \mathrm{H}_{64}$ & 2.56 & - & 2.20 & - & 6.29 & - \\
\hline Heptacosane & $\mathrm{C}_{27} \mathrm{H}_{56}$ & 7.46 & - & 9.26 & - & 9.10 & 1.50 \\
\hline Heptadecanoic acid & $\mathrm{C}_{17} \mathrm{H}_{34} \mathrm{O}_{2}$ & - & 0.19 & - & 0.14 & - & 0.27 \\
\hline Heptadecanoic acid, ethyl ester & $\mathrm{C}_{19} \mathrm{H}_{40} \mathrm{O}_{2}$ & - & - & - & - & - & 0.12 \\
\hline 1-Heptatriacotanol & $\mathrm{C}_{37} \mathrm{H}_{76} \mathrm{O}$ & - & - & - & 0.77 & - & - \\
\hline Hexacosane & $\mathrm{C}_{26} \mathrm{H}_{54}$ & 9.62 & - & 11.50 & - & 10.97 & - \\
\hline Hexadecanamide & $\mathrm{C}_{16} \mathrm{H}_{33} \mathrm{NO}$ & 1.97 & 0.19 & 2.25 & 0.29 & 1.58 & 0.30 \\
\hline$n$-Hexadecanoic acid & $\mathrm{C}_{16} \mathrm{H}_{32} \mathrm{O}_{2}$ & - & 15.14 & - & 19.36 & - & 7.90 \\
\hline Hexadecanoic acid, ethyl ester & $\mathrm{C}_{18} \mathrm{H}_{36} \mathrm{O}_{2}$ & - & 2.64 & - & 9.22 & - & 3.50 \\
\hline Hexatriacontane & $\mathrm{C}_{36} \mathrm{H}_{74}$ & 1.36 & - & 1.61 & & 1.74 & \\
\hline $\begin{array}{l}\text { 2-Hydroxy-5-methylisophthalaldehyde } \\
3 \text { - Isopropyl - } 6 \text { - methylene - 1, 2, 3, 3a, 4, }\end{array}$ & $\mathrm{C}_{9} \mathrm{H}_{8} \mathrm{O}_{3}$ & - & - & - & 0.31 & - & 0.61 \\
\hline $\begin{array}{l}5,6,6 a, 7,12 \text { - decahydrocyclopenta [d] } \\
\text { anthracene-8,11-dione }\end{array}$ & $\mathrm{C}_{21} \mathrm{H}_{26} \mathrm{O}_{2}$ & - & - & 0.76 & - & - & - \\
\hline Lidocaine & $\mathrm{C}_{14} \mathrm{H}_{22} \mathrm{~N}_{2} \mathrm{O}$ & 0.35 & - & 0.22 & - & 0.25 & - \\
\hline Linoleic acid & $\mathrm{C}_{18} \mathrm{H}_{32} \mathrm{O}_{2}$ & - & 1.43 & - & 1.98 & - & 0.69 \\
\hline Linolenic acid & $\mathrm{C}_{18} \mathrm{H}_{30} \mathrm{O}_{2}$ & - & 4.58 & - & 4.56 & - & 2.72 \\
\hline $\begin{array}{l}\text { Linolenic acid, 2-hydroxy-1-(hydroxy- } \\
\text { methyl)ethyl ester (Z,Z,Z)- }\end{array}$ & $\mathrm{C}_{21} \mathrm{H}_{36} \mathrm{O}_{4}$ & - & 0.18 & - & 0.53 & - & - \\
\hline Linolenic acid, ethyl ester & $\mathrm{C}_{20} \mathrm{H}_{36} \mathrm{O}_{2}$ & - & 2.35 & - & 5.46 & - & 3.97 \\
\hline Lupeol acetate & $\mathrm{C}_{32} \mathrm{H}_{52} \mathrm{O}_{2}$ & 6.20 & 1.10 & - & & 0.78 & 8.10 \\
\hline 24-Methylenecycloartan-3-one & $\mathrm{C}_{31} \mathrm{H}_{50} \mathrm{O}$ & - & - & - & 0.67 & - & - \\
\hline $\begin{array}{l}\text { 3-(1-Methylhept-1-enyl)-5-methyl-2,5- } \\
\text { dihydrofuran-2-one }\end{array}$ & $\mathrm{C}_{13} \mathrm{H}_{20} \mathrm{O}_{2}$ & - & 0.58 & - & - & - & - \\
\hline Nonacosane & $\mathrm{C}_{29} \mathrm{H}_{60}$ & 4.09 & - & 5.27 & - & 8.18 & - \\
\hline Octacosane & $\mathrm{C}_{28} \mathrm{H}_{58}$ & 5.56 & - & 7.19 & - & 7.11 & - \\
\hline Octadecanamide & $\mathrm{C}_{18} \mathrm{H}_{37} \mathrm{NO}$ & 1.29 & 0.16 & 1.70 & 0.20 & 1.21 & 0.16 \\
\hline Octadecanoic acid & $\mathrm{C}_{18} \mathrm{H}_{36} \mathrm{O}_{2}$ & - & 1.96 & - & 3.32 & - & 3.06 \\
\hline Octadecanoic acid, ethyl ester & $\mathrm{C}_{20} \mathrm{H}_{42} \mathrm{O}_{2}$ & - & 0.57 & - & 0.53 & - & 1.43 \\
\hline (Z)-9-Octadecenamide & $\mathrm{C}_{18} \mathrm{H}_{35} \mathrm{NO}$ & 20.40 & 2.14 & 25.50 & 2.77 & 23.36 & 2.57 \\
\hline Olean-12-en-3-one & $\mathrm{C}_{30} \mathrm{H}_{48} \mathrm{O}$ & - & - & - & - & - & 0.64 \\
\hline Pentacosane & $\mathrm{C}_{25} \mathrm{H}_{52}$ & 9.32 & - & 10.44 & - & 9.82 & - \\
\hline Pentadecanoic acid & $\mathrm{C}_{15} \mathrm{H}_{30} \mathrm{O}_{2}$ & - & 0.11 & - & 0.17 & - & - \\
\hline Phenol, 2-propyl- & $\mathrm{C}_{9} \mathrm{H}_{12} \mathrm{O}$ & - & - & - & - & - & 7.24 \\
\hline Phytol & $\mathrm{C}_{20} \mathrm{H}_{40} \mathrm{O}$ & 0.94 & 5.31 & 0.28 & 6.58 & 0.05 & 2.99 \\
\hline Phytol, acetate & $\mathrm{C}_{22} \mathrm{H}_{42} \mathrm{O}_{2}$ & - & 5.34 & - & 5.95 & - & 1.44 \\
\hline Simiarenol & $\mathrm{C}_{30} \mathrm{H}_{50} \mathrm{O}$ & - & - & - & - & - & 0.46 \\
\hline$\beta$-Sitosterol & $\mathrm{C}_{29} \mathrm{H}_{50} \mathrm{O}$ & 4.31 & 8.13 & 2.65 & 14.55 & 1.30 & 4.84 \\
\hline Squalene & $\mathrm{C}_{30} \mathrm{H}_{50}$ & 0.63 & 6.75 & - & 2.02 & 0.14 & 4.38 \\
\hline Stigmasterol & $\mathrm{C}_{29} \mathrm{H}_{48} \mathrm{O}$ & 0.30 & 0.42 & 0.52 & 2.29 & & 0.35 \\
\hline Tetracosane & $\mathrm{C}_{24} \mathrm{H}_{50}$ & 7.21 & - & 7.28 & - & 7.04 & - \\
\hline Tetradecanoic acid & $\mathrm{C}_{14} \mathrm{H}_{28} \mathrm{O}_{2}$ & - & - & - & - & - & 0.22 \\
\hline 3,7,11,15-Tetramethyl-2-hexadecen-1-ol & $\mathrm{C}_{20} \mathrm{H}_{40} \mathrm{O}$ & - & 2.61 & - & 2.43 & - & 0.62 \\
\hline dl- $\alpha$-Tocopherol & $\mathrm{C}_{31} \mathrm{H}_{52} \mathrm{O}_{3}$ & 2.31 & 5.26 & - & 0.57 & 0.45 & 3.86 \\
\hline$\gamma$-Tocopherol & $\mathrm{C}_{28} \mathrm{H}_{48} \mathrm{O}_{2}$ & 2.44 & 4.78 & - & 0.60 & & 0.79 \\
\hline$\delta$-Tocopherol & $\mathrm{C}_{28} \mathrm{H}_{48} \mathrm{O}_{2}$ & - & 0.26 & 0.53 & 2.07 & 0.34 & 1.02 \\
\hline Triacontane & $\mathrm{C}_{30} \mathrm{H}_{62}$ & 2.47 & - & 3.33 & - & 3.66 & - \\
\hline 2,4,6-Trihydroxybenzoic acid & $\mathrm{C}_{7} \mathrm{H}_{6} \mathrm{O}_{5}$ & - & - & - & - & - & 3.02 \\
\hline Vitamin E & & - & 0.35 & - & 0.43 & - & 0.16 \\
\hline
\end{tabular}



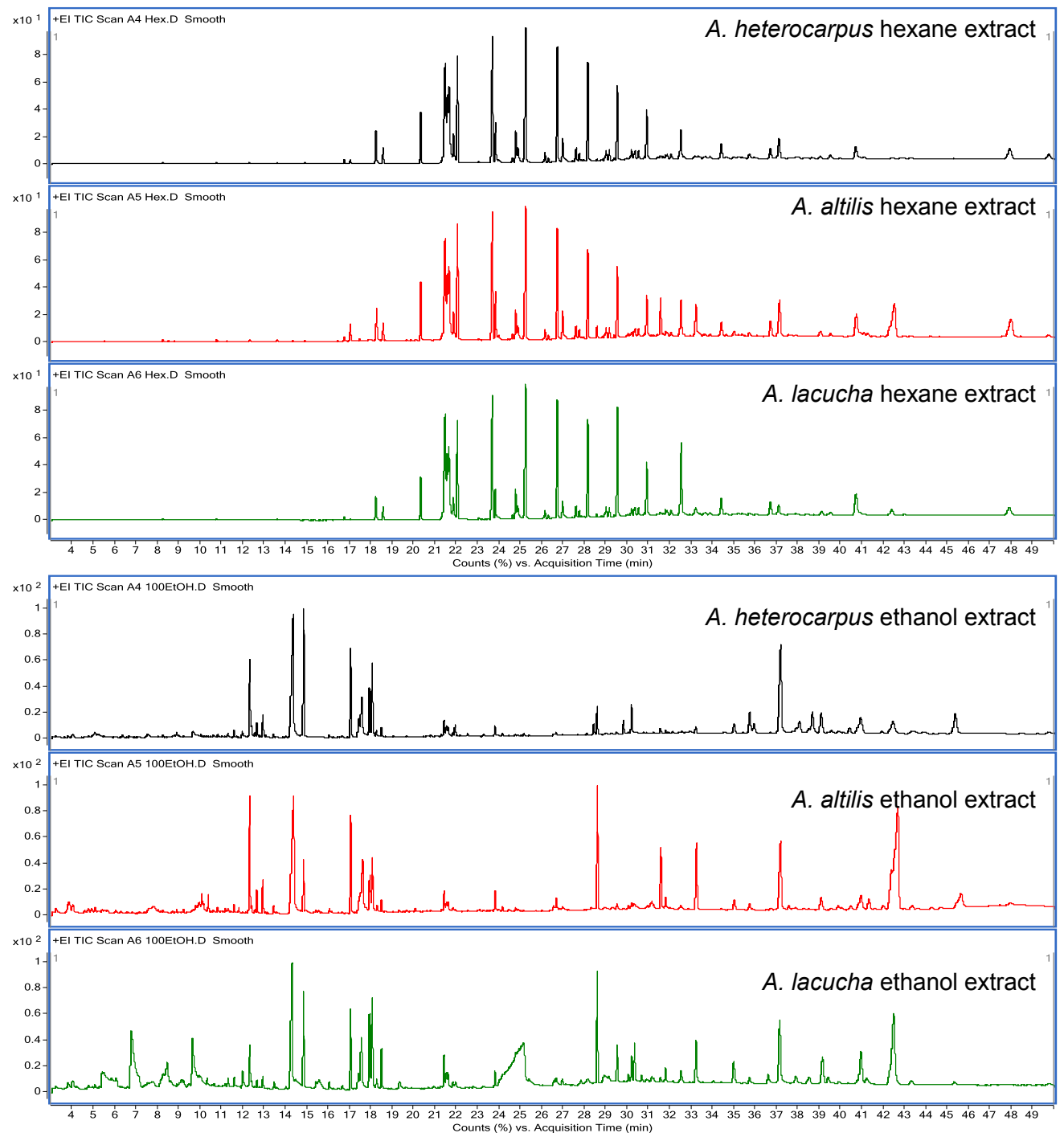

Fig. 1 Chromatograms of hexane and ethanol extracts from the leaves of A. altilis, A. heterophyllus, and A. lacucha.

$\mathrm{IC}_{50}$ value of $0.00035 \mathrm{mg} / \mathrm{ml}$ with calculated $\mathrm{LD}_{50}$ of $71.51 \mathrm{mg} / \mathrm{kg}$. The predicted $\mathrm{LD}_{50}$ dose demonstrated that the $A$. altilis extracts belong to Class II $(50-2000 \mathrm{mg} / \mathrm{kg}$ body weight, oral), moderately hazardous toxic chemicals according to $\mathrm{WHO}^{22}$. All extracts of $A$. heterophyllus and A. lacucha displayed cell viability percentages at $77 \pm 15$ and $62 \pm 27$ indicating cell viabilities of higher than $50 \%$. Hence no $\mathrm{IC}_{50}$ values were calculated.

In addition $\mathrm{IC}_{50}$ values of the ethanol $A$. altilis and $A$. lacucha extracts were 0.868 and $0.218 \mathrm{mg} / \mathrm{ml}$ with calculated $\mathrm{LD}_{50}$ of 1309.57 and $783.26 \mathrm{mg} / \mathrm{kg}$. Predicted $\mathrm{LD}_{50}$ dose demonstrated that all tested compounds of A. altilis and A. lacucha which also belong to the Class II of toxic chemicals. None exhibited $\mathrm{IC}_{50}$ value of $A$. heterophyllus, indicating cell viability percentage of $64 \pm 13$ (Fig. 2).

The extracts at $\mathrm{IC}_{50}$ values, $0.00035 \mathrm{mg} / \mathrm{ml}$ of hexane A. altilis, $0.868 \mathrm{mg} / \mathrm{ml}$ of ethanol A. altilis and $0.218 \mathrm{mg} / \mathrm{ml}$ of ethanol A. lacucha, as well as the highest concentrations of the species absent $\mathrm{IC}_{50}$ values including $2 \mathrm{mg} / \mathrm{ml}$ of hexane $A$. heterophyllus, $2.45 \mathrm{mg} / \mathrm{ml}$ of hexane $A$. lacucha and $9.4 \mathrm{mg} / \mathrm{ml}$ of ethanol A. heterophyllus were selected for further genotoxicity testing via comet assay. The results of comet assay showed that the hexane extracts of the three sample species exhibited no induced DNA damage in PBMCs, as indicated in Fig. 3 when compared to negative control, which was considered as the statistically non-significant DNA damage ( $p>$ 0.05). Meanwhile, the ethanol extracts inducing DNA damage in the cells displayed significant DNA 

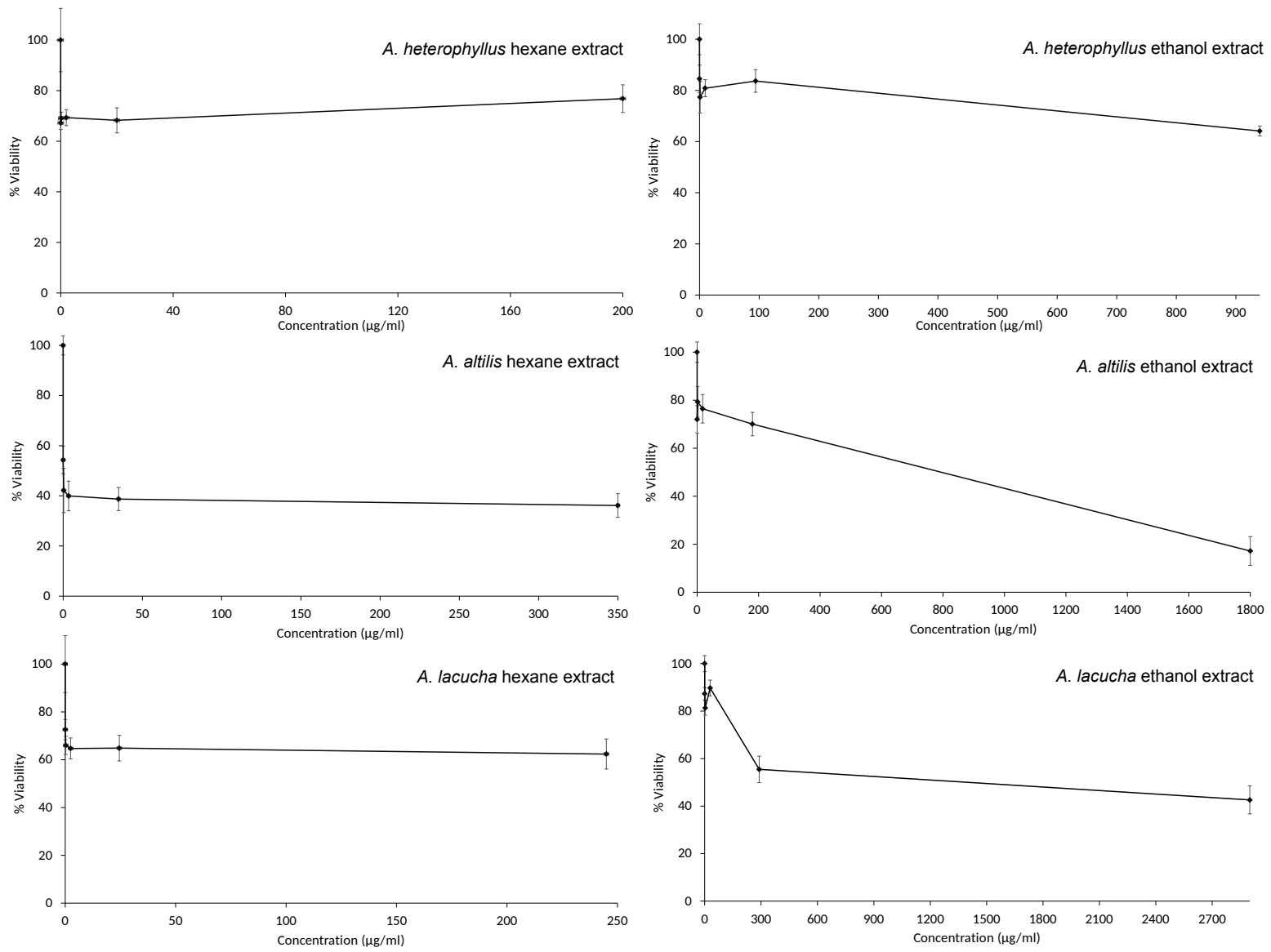

Fig. 2 Cytotoxicity tests of A. altilis, A. heterophyllus, and A. lacucha leaf hexane and ethanol extracts on human PBMCs. Percentages of cell viability are averaged from 3 replicate treatments.

Table 2 Comet assay results showing median of OTM of the PBMCs treated with the 6 extracts of three Artocarpus species. The numbers are averages of 150 cells from each of the three replicate treatments.

\begin{tabular}{lcccc}
\hline Plant & \multicolumn{4}{c}{ OTM } \\
\cline { 2 - 5 } & Control & Hexane & $p$ val. & Ethanol \\
\hline A. altilis & $0.92 \pm 0.73$ & $0.99 \pm 0.77$ & 0.940 & $2.6 \pm 2.2^{*}$ \\
A. heterophyllus & $1.01 \pm 0.95$ & $0.76 \pm 0.62$ & 0.103 & $2.6 \pm 2.9^{*}$ \\
A. lacucha & $0.92 \pm 0.73$ & $0.91 \pm 0.84$ & 0.286 & $1.20 \pm 0.70^{*}$
\end{tabular}

" $p<0.0001$.

damage $(p<0.05)$ (Table 2$)$. Presumably, these results are due to the fact that there are more polar than non-polar phytochemicals receiving high concentrations from ethanol extracts than hexane extracts.

In actuality, the phytochemicals contained within, are important factors for applying the appropriate plants to the appropriate treatments. Phyto- chemical functions ought to be concentrated on the substances at a high amount enough to be used despite hexane or ethanol solvent extractions. Besides that there are many significant phytochemicals identified in Artocarpus extracts. (Z)-9-Octadecenamide or oleamide, for example, was discovered at 20$26 \%$, which is a substance important in human mechanisms. Furthermore it has been shown to be a protective agent against scopolamine-induced memory loss and is suggested to be a useful chemopreventive agent against Alzheimer's disease tested in vitro as well as mice at sufficient quantity ${ }^{24,25}$. Here, a lower percentage may be applied. 9,19Cyclolanost-24-en-3-ol found at 21\% also known as cycloartenol, is an important triterpenoid in the sterol class which is found solely in plants. This is the starting subject for the synthesis of almost all plant steroids ${ }^{26}$. $n$-Hexadecanoic acid or palmitic acid, found at $15-19 \%$, is a type of fatty acid. Also, $\beta$-sitosterol, one of the important phytosterol is beneficial for an array of human symptomatic treat- 


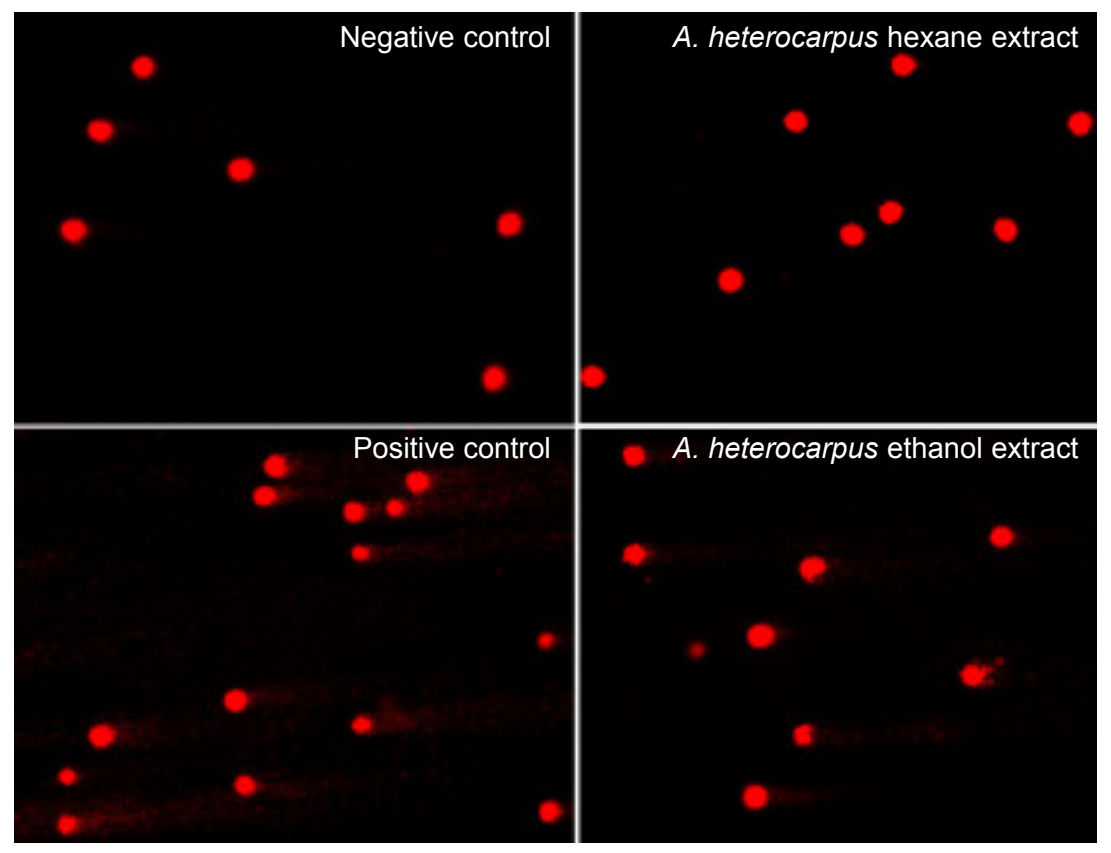

Fig. 3 Comet assay images of PBMCs showing no DNA damages in negative control cells and cells treated with hexane extract and significant DNA damages in positive control cells and cells treated with ethanol extract. Similar figures are not shown.

ments when utilized at suitable concentrations ${ }^{27}$, i.e., at a rather low amount of $15 \%$.

The most important phytochemical finding is arbutin in a high quantity at $21 \%$, which is enough for actual use, as lower than $4 \%$ in health products has been tested to be safe for human consumption. Arbutin is a hydroquinone derivative that has been found in species of several plant genera, such as Arctostaphylos, Bergenia, Lathyrus, Origanum, Pyrus, and Vaccinium ${ }^{28-32}$. It is functioned as a tyrosinase inhibitor, which inhibits mammalian melanogenesis and is responsible for enzymatic browning reactions in damaged fruits during post-harvest handling and processing ${ }^{28}$. Thus it is used in a variety of cosmetics, particularly those aimed at lightening the skin, spot treatments, creams, lotions, soaps, serums and cleaners. The percentages found are rather similar as in the previous reported plants. Due to patent specifications, most skin care products contain plant extracts containing arbutin, for instance, bearberry (Arctostaphylos uva-ursi), pear (Pyrus pyrifolia) and lingonberry (Vaccinium vitis-idaea) rather than pure arbutin. Additional application of arbutin reasoned from tyrosinase function is that it may be used in fruit preservation ${ }^{31-33}$.

Essentially, each phytochemical has specific functions, though not all are known. Hence for safe human usage, the testing of total substances contained for their cytotoxicity and genotoxicity was performed. Additionally, vehicle control (DMSO) was proved not to induce cell death at the highest $(10 \%)$ tested concentration in PBMCs ${ }^{17}$. Hence those effects mentioned above are attributed only to the bioactive compounds of the plant extracts. Testing the effects of compounds on the viability of cells grown in culture is widely used as a predictor of potential toxic effect in whole animals ${ }^{34}$. Cytotoxicity assay revealed that all the extracts belong to Class II. However, there are no chemicals of interest in a high enough amount for treatments. For the A. lacucha extract with arbutin at a high quantity, it can certainly be utilized because low dose of arbutin is needed. Nonetheless, the comet assay result should be combined for consideration of the daily dose consumption.

All chemicals amid the three species studied induced DNA damage, though they were present in rather high concentrations.

Amid daily life, it is impossible to consume high doses per kilogram of body weight, as they present toxicity at over $500 \mathrm{mg} / \mathrm{kg}$ body weight when consumed orally. The authors suggest that applications of arbutin at concentration lower than $4 \%{ }^{33}$ may be used in a limited amount, during a limited time frame. The research revealed that the species of most interest, A. lacucha, contained high amounts 
of arbutin; an alternative choice of arbutin in the context of Thailand. Artocarpus species are mainly distributed in Southeast Asia ${ }^{35}$ and highly related to culture and life of the residences. These three studied species were listed as important species ${ }^{36}$ among 50 species of the genus ${ }^{37}$. There have been reports on traditional uses as folk medicines ${ }^{35-37}$. Leaves of all the three species have been consumed as tea or foods. In Thailand, people have eaten young leaves of $A$. heterophyllus in wrapping tidbits. Furthermore, the $A$. heterophyllus leaves have been used as antisyphilitic and vermifuge agents, and for ulcer and wound healing, and its leaves and stem bark used to treat anaemia, asthma, dermatitis, diarrhoea, and coughs ${ }^{37}$. Formerly, resveratrol and oxyresveratrol were found in A. lacucha heartwood which has been used for inhibiting melanogene$\operatorname{sis}^{20,38,39}$. It can be used, though heartwood is cut from the stem, destroying the plants. Promisingly, leaves can be grown at any time, so they are worthwhile and sustainable amid application.

Arbutin or hydroquinone-beta-D-glucoside is one of the most important phytochemicals that have been used for health products, especially cosmetics. It was found in various plant species such as bearberry, blueberry, cranberry and mulberry. Arbutin is functioning as tyrosinase inhibitor which inhibits mammalian melanogenesis. Thus it is used in a variety of cosmetics such as spot treatments, creams, lotions, soaps, serums and cleaners, particularly those aimed at lightening the skin.

Even though its ethanol extract can induce DNA damage, this study suggested that, based on applications of arbutin lower than $4 \%$ in health products, usage in low amount can be safe for human consumption.

This study screens for phytochemical constituents in the three herbal edible plants including A. altilis, A. heterophyllus, and A. lacucha which are popularly grown and used as foods and medicines among the others in the genus. Arbutin was firstly reported in A. lacucha leaf with high quantity at $21 \%$. It has never been reported in any Thai plants. Additionally, its existence in the leaves leads to convenient and sustainable use, the plant leaves can be high efficient sources of arbutin for cosmetic factories. However, its ethanol extract can induce DNA damage on human peripheral blood mononuclear cells. Hence the safety uses should be considered and further studies for its appropriate dose are required.

Acknowledgements: This study is financially supported by the 2015 TTSF Science \& Technology Research Grant, Toray Science Foundation, Japan and Genetics and Environmental Toxicology Research Group, Khon Kaen University. All the authors confirm that they have no conflict of interest.

\section{REFERENCES}

1. Golomb BA, Evans MA (2008) Statin adverse effects: a review of the literature and evidence for a mitochondrial mechanism. Am J Cardiovasc Drugs 8, 373-418.

2. Di Stasi SL, MacLeod TD, Winters JD, BinderMacleod SA (2010) Effects of statins on skeletal muscle: a perspective for physical therapists. Phys Ther 90, 1530-42.

3. Mysore V (2012) Finasteride and sexual side effects. Indian Dermatol Online $J$ 3, 62-5.

4. Patil SM, Sapkale GN, Surwase US, Bhombe BT (2010) Herbal medicines as an effective therapy in hair loss: a review. Res J Pharmaceut Biol Chem Sci 1, 773-81.

5. Kumar N, Rungseevijitprapa W, Narkkhong NA, Suttajit M, Chaiyasut C (2012) $5 \alpha$-reductase inhibition and hair growth promotion of some Thai plants traditionally used for hair treatment. $J$ Ethnopharmacol 139, 765-71.

6. Ras RT, Geleijnse JM, Trautwein EA (2014) LDLcholesterol-lowering effect of plant sterols and stanols across different dose ranges: a meta-analysis of randomized controlled studies. Br J Nutr 112, 214-9.

7. Saeidnia S, Manayi A, Gohari AR, Abdollahi M (2014) The story of beta-sitosterol: a review. Eur $J$ Med Plant 4, 590-609.

8. Li Y, Han M, Lin P, He Y, Yu J, Zhao R (2015) Hair growth promotion activity and its mechanism of Polygonum multiflorum. Evid Based Complement Altern Med 2015, 517901.

9. Jaber BM, Jasim SF (2014) Phytochemical study of stigmasterol and $\beta$-sitosterol in Viola odorata plant cultivated in Iraq. Iraqi J Biotechnol 13(2), 86-94.

10. Sudmoon R, Chaveerach A, Tanee T (2016) Analysis of genetics and chemical contents relation compared to commonly used Cissus quadrangularis L. and barcode markers of some Thailand Cissus species. Pakistan J Pharmaceut Sci 29, 65-75.

11. Sanubol A, Chaveerach A, Sudmoon R, Tanee T, Noikotr K, Chuachan C (2014) Betel-like-scented Piper plants as diverse sources of industrial and medicinal aromatic chemicals. Chiang Mai J Sci 41, 1171-81.

12. Suwannakud KS, Sudmoon R, Tanee T, Chaveerach A (2014) Genetic relations related to chemical containing and the efficient barcodes by psbA-trn $\mathrm{H}$ spacer and its combinations with $r b c \mathrm{~L}$ and matK on Gardenia species. J Appl Biol Sci 8(3), 65-78. 
13. Rigotti A (2007) Absorption, transport and tissue delivery of vitamin E. Mol Aspect Med 28, 423-36.

14. Chaveerach A, Aungkapattamagul S, Tanee T, Noikotr K, Sudmoon R (2014) Genetic verification and chemical contents identification of Allamanda species (Apocynaceae). Pakistan J Pharmaceut Sci 27, 417-24.

15. Taweechaisupapong S, Singhara S, Lertsatitthanakorn P, Khunkitti W (2010) Antimicrobial effects of Boesenbergia pandurata and Piper sarmentosum leaf extracts on planktonic cells and biofilm of oral pathogens. Pakistan J Pharmaceut Sci 23, 224-31.

16. Nadir M, Rasheed M, Sherwani SK, Kazmi SU, Ahmad VU (2013) Chemical and antimicrobial studies on the essential oil from Salvia santolinifolia Boiss. Pakistan J Pharmaceut Sci 26, 39-52.

17. Chaveerach A, Lertsatitthanakorn P, Tanee T, Puangjit N, Patarapadungkit N, Sudmoon R (2016) Chemical constituents, antioxidant property, cytotoxicity and genotoxicity of Tiliacora triandra. Int $J$ Pharmacogn Phytochem Res 8, 722-9.

18. Maneechai S, Likhitwitayawuid K, Sritularak B, Palanuvej C, Ruangrungsi N, Sirisa-ard P (2009) Quantitative analysis of oxyresveratrol content in Artocarpus lakoocha and 'puag-haad'. Med Princ Pract 18, 223-7.

19. Chatsumpun N, Chuanasa T, Sritularak B, Lipipun V, Jongbunprasert V, Ruchirawat S, Ploypradith P, Likhitwitayawuid K (2016) Oxyresveratrol: structural modification and evaluation of biological activities. Molecules 21, 489.

20. Rodboon T, Puchadapirom P, Okada S, Suwannalert P (2016) Oxyresveratrol from Artocarpus lakoocha Roxb. inhibit melanogenesis in B16 melanoma cells through the role of cellular oxidants. Walailak $J$ Sci Tech 13, 261-70.

21. Walum E (1998) Acute oral toxicity. Environ Health Perspect 106(suppl 2), 497-503.

22. World Health Organization (2009) The WHO Recommended Classification of Pesticides By Hazard And Guidelines To Classification, WHO, Geneva.

23. Singh NP, McCoy MT, Tice RR, Schneider EL (1988) A simple technique for quantitation of low levels of DNA damage in individual cells. Exp Cell Res 175, 184-91.

24. Heo HJ, Park YJ, Suh YM, Choi SJ, Kim MJ, Cho HY, Chan YJ, Hong B, et al (2003) Effects of oleamide on choline acetyltransferase and cognitive activities. Biosci Biotechnol Biochem 67, 1284-91.

25. Thooptianrat T, Chaveerach A, Sudmoon R, Tanee T, Liehr T, Babayan N (2017) Screening of phytochemicals and toxicity of medicinal plants, Dillenia species, reveals potential natural product resources. J Food Biochem 41, e12363.

26. Schaller H (2003) The role of sterols in plant growth and development. Progr Lipid Res 42, 163-75.

27. Gajewski M, Przybył JL, Kosakowska O, Szymczak P
(2009) Some factors influencing free sterols content in broccoli (Brassica oleracea L. var. botrytis italica Plenck.). J Food Biochem 33, 881-94.

28. Chang TS (2009) An updated review of tyrosinase inhibitors. Int J Mol Sci 10, 2440-75.

29. Pop C, Vlase L, Tamas M (2009) Natural resources containing arbutin, determination of arbutin in the leaves of Bergenia crassifolia (L.) Fritsch. acclimated in Romania. Not Bot Horti Agrobot Cluj-Napoca 37, 129-32.

30. Lukas B, Schmiderer C, Mitteregger U, Novak J (2010) Arbutin in marjoram and oregano. Food Chem 121, 185-90.

31. Lee BD, Eun JB (2012) Optimum extraction conditions for arbutin from Asian peal peel by supercritical fluid extraction (SFE) using Box-Behnken design. $J$ Med Plant Res 6, 2348-64.

32. Pizzorno J, Murray M (2013) Textbook of Natural Medicine, Churchill Livingstone, Elsevier, St. Louis, MO.

33. National Toxicology Program (2006) Chemical information review document for arbutin [CAS No. 497-76-7] and extracts from Arctostaphylos uva-ursi, NTP, National Institutes of Health, US Department of Health and Human Services, Research Triangle Park, NC.

34. National Toxicology Program (2009) Report on the ICCVAM-NICEATM/ECVAM/JaCVAM Scientific Workshop on Acute Chemical Safety Testing: Advancing In Vitro Approaches and Humane Endpoints for Systemic Toxicity Evaluations, NTP, National Institutes of Health, US Department of Health and Human Services, Research Triangle Park, NC.

35. Williams EW, Gardner EM, Harris R 3rd, Chaveerach A, Pereira JT, Zerega NJC (2017) Out of Borneo: biogeography, phylogeny and divergence date estimates of Artocarpus (Moraceae). Ann Bot 119, 611-27.

36. Akhil H, Revikumar KG, Divya D (2014) Artocarpus: a review of its phytochemistry and pharmacology. J Pharma Search 9, 7-12.

37. Jagtap UB, Bapat VA (2010) Artocarpus: a review of its traditional uses, phytochemistry and pharmacology. J Ethnopharmacol 129, 142-66.

38. Povichit N, Phrutivorapongkul A, Suttajit M, Leelapornpisid P (2010) Antiglycation and antioxidant activities of oxyresveratrol extracted from the heartwood of Artocarpus lakoocha Roxb. Maejo Int J Sci Tech 4, 454-61.

39. Suwannalert P, Povichit N, Puchadapirom P, Junking M (2012) Anti-aging activity and non-toxic dose of phytooxyresveratrol from Artocarpus lakoocha Roxb. Trop J Pharmaceut Res 11, 69-74. 